in in vitro fertilisation, but appreciable side effects are unlikely to be so rare. For instance, ovarian hyperstimulation is a known risk despite published advice that it should be preventable. ' Adequate information about possible morbidity in assisted conception is not made readily available to potentia patients, nor are the hazards apparently sufficiently acknowledged by those who deliver the treatments

Of course, the increasing success of fertility treatments is to be welcomed, but childless couples, in their desperate longing for babies, are only too ready to overlook the possible drawbacks. Fertility specialists therefore have a duty to present comprehensive information about not only the prospects of success but also the risks of assisted conception.

Warley Hospital,

BILI. TRAVERS

Brentwood, Essex CM14 5HQ

1-Hull MGR, Eddowes HA, Fahy U, Abuzeid MI, Mills MS, Cahill DJ, et al. Expectations of assisted conception for infertility. $B M 7$ 1992;304:1465-9. (6 June.)

2 Smith BH, Cooke ID. Ovarian hyperstimulation: actual and theoretical risks. BMf 1991;302:127-8. (19 January.)

EDITOR,-M G R Hull and colleagues' article confirms the positive role of assisted conception. We have several comments.

Firstly, Hull and colleagues are right to question the validity of the legal constraint on the number of eggs and embryos that can be transferred in gamete intrafallopian transfer and in vitro fertilisation. This is especially relevant to women aged 40 or above, who have a low chance of becoming pregnant after assisted conception. ${ }^{23}$ The incidence of multiple pregnancy in this age group is low even when more than three eggs or embryos are transferred, as confirmed in Hull and colleagues' and other studies. ${ }^{2}$ We have long argued for flexibility that allows a variable number of eggs or embryos to be transferred to suit the circumstances of individual couples.

Secondly, Hull and colleagues report a significantly higher pregnancy rate with gamete intrafallopian transfer than with in vitro fertilisation or high intrauterine insemination, which also confirms our experience. The difference in pregnancy rates between gamete intrafallopian transfer and in vitro fertilisation has recently narrowed owing to improvements in in vitro fertilisation and because limiting the number of eggs allowed to be transferred in gamete intrafallopian transfer has a greater effect on reducing the pregnancy rate than limiting the number of embryos transferred in in vitro fertilisation.

Thirdly, the authors' projected cumulative pregnancy rate of $82 \%$ after six attempts of in vitro fertilisation or gamete intrafallopian transfer is encouraging, but even better results could have been obtained sooner, and with fewer attempts, if cryopreservation of embryos had been available.

The pregnancy rate after replacement of thawed embryos in our centre in 1991 was $28 \%$ per frozen embryo replacement ( 22 out of 79 cycles). During the same year 275 cycles of gamete intrafallopian transfer and 263 cycles of in vitro fertilisation were performed. The clinical pregnancy rate was $32 \%$ after gamete intrafallopian transfer and $24 \%$ after in vitro fertilisation $(40 \%$ and $26 \%$ respectively for women under 40). Including frozen embryo replacement results in a projected cumulative pregnancy rate of $60 \%$ for gamete intrafallopian transfer and $52 \%$ for in vitro fertilisation after a single superovulation egg retrieval cycle $(69 \%$ and $54 \%$ respectively for women under 40 ).

Cryopreservation of suitable embryos should be an integral part of assisted conception programmes to increase cumulative pregnancy rates and reduce costs and the need for repeated superovulation and egg retrieval.

TALHA AL-SHAWAF

IAN CRAFT

London Fertility Centre and Medicraft Services,

London WIN IAF
I Hull MGR, Eddowes HA, Fahy U, Abuzeid MI, Mills MS, Cahill DJ, et al. Expectations of assisted conception for infertility. BMJ 1992;304:1465-9. (6 June.)

2 Craft IL, Ah-Moye M, Al-Shawaf T, Fiamanya W, Lewis $P$ Robertson D, et al. Analysis of 1071 GIFT procedures - the Al-Se for a fexible approach to treatment. Lancet 1988;1:1094-8. The infuence of o, Guirgis $R$, Harper J, Sancis $M$, The inflence of ovarian response on gamete intrafallopia transfer outcome in older aged women. Hum Reprod (in press).

\section{Cancer chemotherapy and fertility}

EDIToR,- When quality of life during and after cancer chemotherapy is being considered ${ }^{\prime}$ the loss of gonadal function, with the consequence of infertility, should also be taken into account. Increasing numbers of male and female patients are surviving chemotherapy for cancer in childhood and the reproductive years. Reproductive capability may be a major factor when contemplating their prospective quality of life.

Research is in progress at the Royal London Hospital to determine the precise effects of chemotherapy on fertility. Alkylating agents, for instance, have a substantial deleterious action on the gonads, leading to the possibility that chemotherapeutic substitution may give a better prognosis for fertility without prejudicing the outcome of treatment.

We believe that fertility is an important factor in the quality of life and should be discussed during counselling before and after treatment. It should be taken into account when deciding on the timing of chemotherapy and the protocol. If gonada damage is deemed inevitable then, when possible, gamete preservation should be offered.

NIGEL F PERKS ADRIAN M LOWER STEPHEN M KELSEY

Royal London Hospital Trust,

London E1 1BB

1 Byrne M. Cancer chemotherapy and quality of life. BMF 1992;304:1523-4. (13 June.)

\section{Steroid receptors in early breast cancer}

EDITOR, - In reviewing recent developments in the management of early breast cancer $R$ D Rubens, discussing risk evaluation, plays down the role of measurement of steroid receptor concentrations. Nevertheless, several reports have shown steroid receptor concentrations to have prognostic value in early, node negative breast cancer treated without adjuvant therapy..$^{2-4}$

We have measured, by enzyme immunoassays, oestrogen receptor and progesterone receptor concentrations in tumours $(61 \% \leqslant 2 \mathrm{~cm})$ of 130 patients entered into a prospective randomised trial comparing different regimens of radiotherapy in women with clinically node negative early breast cancer ( $\leqslant 5 \mathrm{~cm}$ diameter) treated by conservative surgery. All patients in this trial received adjuvant tamoxifen, being further randomised to either continuous treatment or treatment for two years only; this is particularly relevant when the prognostic value of hormone receptor status is being considered.

After a median follow up of 18 (range 0-41) months our results show that, with a cut off of $20 \mathrm{fmol} / \mathrm{mg}$, negative status for both steroid receptors, but particularly oestrogen receptors, is significantly associated with early recurrence (table). All the patients who developed recurrence were taking tamoxifen at the time, and the length of follow up for patients who were negative and positive for oestrogen receptors was similar. Of other available risk factors (size and grade of tumour, menopausal status, $\mathrm{pS} 2$ protein), only the grade of the tumour $\left(\chi^{2}=6.6, p<0.02, n=96\right)$ and
Number of women who were disease free or had recurrence of breast cancer at follow up according to oestrogen receptor and progesterone receptor status

\begin{tabular}{lcccccc}
\hline & \multicolumn{2}{c}{$\begin{array}{c}\text { Oestrogen } \\
\text { receptors }\end{array}$} & & \multicolumn{2}{c}{$\begin{array}{c}\text { Progesterone } \\
\text { receptors }\end{array}$} \\
\cline { 2 - 3 } & Negative & Positive & & Negative Positive \\
\hline Recurrence $(\mathrm{n}=19)$ & 14 & 5 & & 13 & 6 \\
Disease free $(\mathrm{n}=111)$ & 22 & 89 & & 42 & 69 \\
\hline Total & 36 & 94 & & 55 & 75 \\
& $\chi^{2}=20 \cdot 9, \mathrm{p}<<0 \cdot 001$ & & $\chi^{2}=5 \cdot 0, \mathrm{p}=0 \cdot 025$
\end{tabular}

the oestrogen regulated pS2 protein concentration (radioimrunoassay, cut off $1 \mathrm{ng} / \mathrm{ml} ; \chi^{2}=5 \cdot 3$, $\mathrm{p}<0.05, \mathrm{n}=83$ ) were significant. Of the eight deaths related to cancer, six were in women who were negative for both oestrogen receptors and progesterone receptors and all were in women who were negative for at least one steroid receptor.

As Rubens points out when discussing adjuvant therapy, oestrogen receptor concentration has recently been shown to correlate highly significantly with a reduction in annual odds of death with adjuvant tamoxifen. ${ }^{5}$ Our early results are consistent with this observation and suggest that markers of a functionally intact oestrogen response pathway ( $P R$ and pS2) may also have a role in the evaluation of risk. We believe, therefore, that measurement of steroid receptor concentrations in early breast cancer gives valuable prognostic information, particularly for the increasing number of patients treated with adjuvant tamoxifen

P S STONELAKE

Department of Surgery,

Dudley Road Hospital,

Birmingham B18 7QH

Department of Surgery,

Birmingam B15 2TH

P R BAKER

P G BAKER

J M MORRISON

D SPOONER

West Midlands Breast Cancer Group,

Clinical Trials Unit,

Queen Elizabeth Hospital,

Birmingham B15 2TH

1 Rubens RD. Management of early breast cancer. BM 1992;30 1361-4. (23 May.)

2 Thorpe SM, Rose C, Rasmussen BB, Mouridsen HT, Bayer T, Keiding N. Prognostic value of steroid hormone receptors: multivariate analysis of systemically untreated patients with node negative primary breast cancer. Cancer Res 1987;47. 6126-33.

3 Clark GM, McGuire WL. The clinical usefulness of oestrogenreceptor and other markers of hormone dependence. Proceedreceptor and other markers of hormone dependence.
ings of the Royal Society of E dinburgh 1989;958:145-50.

4 Chevallier B, Mosseri V, Dauce JP, Basuyan JP, Bastit P, Julien $\mathrm{JP}$, et al. A prognostic score in histological node negative breast $J \mathrm{P}$, et al. A prognostic score in histolo

5 Early Breast Cancer Trialists' CoHaborative Group. Systemic treatment of early breast cancer by hormonal, cytotoxic, or immune therapy. Lancet 1992;339:1-15, 71-85.

\section{Hyponatraemia in children}

EDIroR, - Allen I Areiff and colleagues emphasise the need for greater awareness that serious electrolyte disturbances can occur in apparently healthy children.' This has important implications as early treatment can appreciably improve their outcome. We treated a previously healthy 11 year old child who suffered serious neurological complications due to water intoxication during a prolonged swimming session with a mixed age group.

On the evening before his admission he trained as a member of the local lifesaving club; swimming for about three hours. During this time he inadvertently swallowed "a lot of water," being splashed by the adult members of the team. Soon after returning home he started vomiting and became agitated and progressively obtunded. There was no history of exposure to toxins or drugs, nor was there any family history of a seizure disorder. 